\title{
PENGEMBANGAN INSTRUMEN PENILAIAN PRAKTIKUM LAPANGAN (OUTDOOR PRACTICUM) BIOLOGI
}

\section{DEVELOPING OF BIOLOGICAL OUTDOOR PRACTICUM ASSESSMENT}

\author{
Hifni Septina Carolina ${ }^{1)}$, Asih Fitriana Dewi, ${ }^{2)}$ Tika Mayang Sari ${ }^{3)}$, \\ Tri Andri Setiawan ${ }^{4}$ \\ Tadris Biologi, Institut Agama Islam Negeri Metro, Lampung \\ Email: Hifnicarolina@metrouniv.ac.id
}

diterima : 1 September 2019; dipublikasi : 30 Oktober 2019

DOI: http://dx.doi.org/10.32528/bioma.v4i2.3163

\begin{abstract}
ABSTRAK
Penelitian ini bertujuan untuk mengembangkan instrumen penilaian praktikum lapangan (outdoor) biologi SMA/MA dan mengetahui kualitas instrumen penilaian tersebut. Penelitian ini menggunakan model pengembangan dengan metode design based research (DBR). Model pengembangan ini terdiri dari: 1) Identifikasi dan analisis masalah oleh peneliti dan praktisi secara kolaboratif, 2) Mengembangkan prototype, 3) Melakukan proses berulang dan menguji prototype, 4) Refleksi menghasilkan produk. Data penelitian dikumpulkan melalui angket validasi ahli, angket respon peserta didik yang dianalisis secara kuantitas dan kualitas Hasil analisis data menunjukkan instrumen penilaian praktikum lapangan dari ahli materi sebesar 89,3 dengan kriteria sangat tinggi, penilaian dari ahli evaluasi sebesar 92,6 dengan kriteria sangat tinggi, dan penilaian ahi desain media sebesar 88,7 dengan kriteria sangat tinggi. Sehingga dapat disimpulkan bahwa pengembangan instrumen penilaian praktikum lapangan (outdoor) biologi dinyatakan layak digunakan.
\end{abstract}

Kata kunci: Pengembangan, Instrumen penilaian, Praktikum Oudoor

\begin{abstract}
This study aims to develop an outdoor biology practicum assessment instrument for high school students and find out the quality of the assessment instruments. This study uses a development model with a design-based research (DBR) method. This development model consists of: 1) Identification and analysis of problems by researchers and practitioners collaboratively, 2) Developing prototypes, 3) Performing repetitive processes and testing prototypes, 4) Reflections produce products. Data collection techniques using expert validation questionnaires, questionnaire responses of students who were analyzed in terms of quantity and quality. The results of the data analysis showed that the instrument for outdoor practicum, assessment from material expert was 89.3 with very high criteria, assesment from evaluation experts was 92.6 with very high criteria, and assessment of media design was 88.7 with very high criteria. It can be concluded that the outdoor biology practicum assessment instrument for high school students is proper to use.
\end{abstract}

Keywords: developing, assessment instruments, outdoor practicum

Hifni Septina Carolina, et al, Pengembangan Instrumen 


\section{PENDAHULUAN}

Kurikulum 2013 adalah kurikulum yang melakukan penyederhanaan, dan tematik integratif, menambah jam pelajaran dan bertujuan untuk mendorong siswa mampu melakukan observasi, bertanya, bernalar, dan mengkomunikasikan (mempersentasikan), apa yang mereka peroleh atau mereka ketahui setelah memiliki materi pembelajaran dan diharapkan siswa memiliki kompetensi sikap, keterampilan, dan pengetahuan jauh lebih baik (Yasbiati, 2014). Sehingga kurikulum 2013 memungkinkan siswa untuk terlibat secara aktif dalam pembelajaran.

Pembelajaran sains harus menekankan pada aktivitas siswa selama kegiatan pembelajaran yang membangun pengetahuan melalui serangkaian kegiatan untuk menciptakan pembelajaran bermakna bagi siswa ( Fuadi, et al, 2015). Salah satu kegiatan pembelajaran yang dapat melatih ketiga kompetensi yaitu kognitif, afektif dan psikomotor adalah kegiatan praktikum di laboratorium (Hazarianti et al., 2016).

Laboratorium merupakan tempat melakukan pengamatan, melakukan percobaan, latihan dan pengujian konsep pengetahuan dan teknologi (Elseria, 2016). Pembelajaran Biologi erat sekali dengan kegiatan praktikum di laboratorium. Praktikum tidak hanya dilakukan di ruang laboratorium, namun juga dilakukan di luar ruangan (Hidayah, 2017, hal 145).

Praktikum, dalam pembelajaran biologi adalah kegiatan eksplorasi serta eksperimen di laboratorium atau di lapangan terbuka untuk memberikan pengalaman langsung kepada siswa (Puspitasari et al., 2019). Saat kegiatan praktikum, siswa dapat melakukan kegiatan pengamatan (observasi), menafsirkan data, meramalkan, menggunakan alat dan bahan, merencanakan praktikum, mengungkapkan hasil praktikum dan mengajukan pertanyaan (Suryaningsih, 2017).

Selama ini penilaian siswa dalam kegiatan praktikum masih belum maksimal. Hal ini diketahui saat observasi dengan guru di MA Al Muhsin dimana penilaian praktikum belum optimal berorientasi pada keterampilan proses sains dan sikap ilmiah siswa. Salah satu penilaian proses dapat dilakukan dengan pengamatan langsung kepada siswa selama kegiatan praktikum Biologi. Menurut Freedman (2002) dalam Chiappetta dan Koballa (2010) menjelaskan bahwa aktifitas praktikum di laboratorium merupakan kegiatan psikomotorik siswa yang dapat membantu siswa memperoleh pengetahuan 
tentang konsep-konsep, prinsip-prinsip, hukum-hukum dasar dan teori yang merupakan hasil dari praktikum yang diperoleh dari pengalaman nyata. Selanjutnya Chiappetta dan Koballa (2010) mengungkapkan,

In general, laboratory work can be used to promote the following learning outcomes: attitudes towards science, sceintific attitudes, scientific inquiry, technical skills and teamwork skills

Berarti bahwa secara umum, kegiatan laboratorium dapat digunakan untuk menghasilkan hasil belajar berupa, sikap terhadap sains, sikap ilmiah, sikap penemuan/penyelidikan, ketrampilan teknis, dan ketrampilan kerjasama. Menurut Charles (2010, Hal. 77) keterampilan proses sains memungkinkan siswa untuk memproses informasi baru melalui pengalaman nyata.

Menurut Toharudin (2011, Hal. 35) Keterampilan proses sains meliputi keterampilan: melakukan pengamatan (observasi), mengkomunikasikan, mengelompokkan (klasifikasi), melakukan pengukuran, membuat kesimpulan, meramalkan, mengidentifikasi variabel, mengidentifikasi tabulasi, mengidentifikasi grafik, mendeskripsikan hubungan variabel, memperoleh dan memproses data, menganalisis penyelidikan, merumuskan hipotesis, melakukan percobaan. Sedangkan ciri-ciri siswa yang memiliki sikap ilmiah antara lain memiliki rasa ingin tahu, tidak menerima kebenaran tanpa bukti, jujur, teliti, menghargai pendapat orang lain, sanggup menerima gagasan baru dan semangat baru (Haerunnisa et al., 2018)

Tujuan dari penelitian ini adalah untuk menghasilkan instrumen penilaian praktikum outdoor Biologi siswa kelas X SMA/MA dan menguji kelayakan instrumen penilaian praktikum outdoor Biologi khususnya penilaian ketrampilan proses dan sikap ilmiah.

\section{METODE}

Penelitian ini menggunakan metode design based research (DBR). Tahapan dalam metode design research menurut Reeves (2006, dalam Plomp, 2007, hal. 14, dalam Lidinillah, 2012, hal. 11) sebagai berikut: 


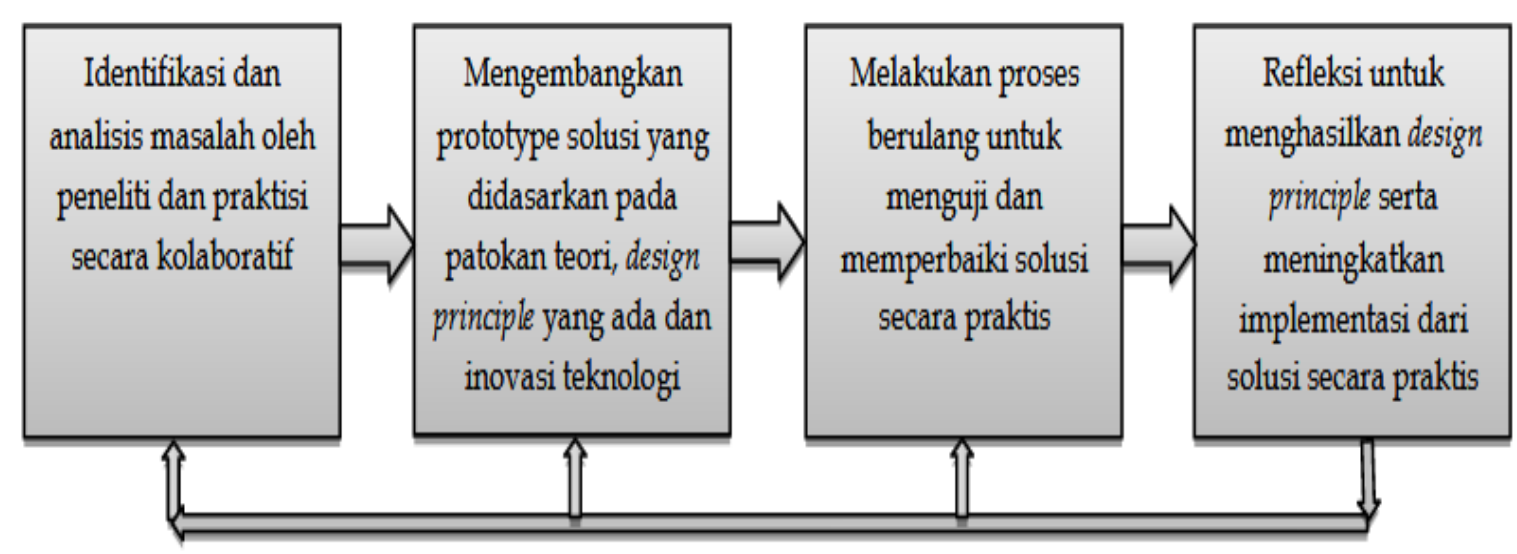

Gambar 1. Diagram Design Research Model Reeves

Instrumen penilaian ini dikembangkan untuk praktikum pada materi Ekosistem. Pelaksanaannya diawali dengan identifikasi dan analisis masalah, selanjutnya hasil pengembangan akan dilakukan penilaian (validasi) oleh para ahli, akan dilakukan revisi jika ada perbaikan dan selanjutnya diujicobakan di kelas X di MA Al Muhsin Metro untuk melihat tingkat kelayakan penggunaan penilaian praktikum outdoor Biologi. Uji coba dilakukan dengan menggunakan rumus validitas dan reliabilitas. Uji validitas dalam penelitian ini adalah rubrik penilaian kinerja praktikum (Arikunto, 2010:65).

Teknik yang digunakan untuk mengetahui kesejajaran adalah teknik korelasi product moment yang dikemukakan oleh Pearson (Arikunto, 2010:69-70). Kriteria validitas instrument dengan nilai $\mathrm{r}$ product momen tergantung jumlah responden.

$$
\mathrm{r}_{\mathrm{xy}}=\frac{n \sum x y-\sum x \sum y}{\sqrt{\left(\mathrm{n} \sum \mathrm{x}^{2}-\left(\sum x\right)^{2}\right)\left(n \sum y^{2}-\left(\sum y\right)^{2}\right.}}
$$

Keterangan:

Rxy = koefisien korelasi pearson

$\mathrm{x} \quad=$ variabel bebas

$\mathrm{y} \quad=$ variabel terikat

$\mathrm{n} \quad=$ jumlah data 
Nilai rxy yang diperoleh akan dikonsultasikan dengan harga $r$ product moment pada tabel pada taraf signifikansi 0,05. Bila $r_{\text {hit }}>r_{\text {tab }}$ maka item tersebut dinyatakan valid.

\section{HASIL DAN PEMBAHASAN}

Hasil penelitian pengembangan instrument penilaian praktikum outdoor Biologi pada materi Ekosistem melalui beberapa tahap sebagai berikut: identifikasi kebutuhan buku ajar terhadap guru/peserta didik, desain produk validasi dan perbaikan desain, uji coba produk skala kecil dan revisi produk.

Berdasarkan analisis kebutuhan dan wawancara dengan guru Biologi di MA Al Muhsin, dibutuhkan lembar penilaian praktikum lapangan (outdoor) yaitu berupa penilaian keterampilan proses sains dan sikap ilmiah peserta didik. Sehingga dilakukan pengembangan instrument penilaian praktikum lapangan (outdoor) Biologi.

Data hasil pada tahap pengembangan pada penelitian ini meliputi data validasi ahli (ahli materi, penyajian materi dan ahli bahasa). Hasil penilaian ahli tersebut disajikan pada tabel 1 berikut ini:

Tabel 1. Hasil Penilaian Ahli Terhadap Instrumen Penilaian Praktikum lapangan (outdoor)

\begin{tabular}{llll}
\hline No & Validator & Nilai $(\%)$ & Kategori \\
\hline 1 & Validator Ahli Materi & 89,3 & Sangat Baik \\
2 & $\begin{array}{l}\text { Validator Ahli } \\
\text { Penyajian materi/ isi }\end{array}$ & 92,6 & Sangat Baik \\
3 & Validator Ahli Bahasa & 88,7 & Sangat Baik \\
\hline Jumlah Seluruhnya & 270,6 & \\
\hline Rata-rata nilai & 90,2 & Sangat Baik \\
\hline
\end{tabular}

Tahap selanjutnya adalah uji coba produk skala kecil dilakukan di MA AlMuhsin Metro di kelas X.5 dengan jumlah siswa sebanyak 18 peserta didik. Pada uji validitas dengan menggunakan rumus product moment. Dikatakan suatu data valid apabila $r_{\text {hitung }}>r_{\text {tabel }}$, menggunakan $\alpha=0,05$ dengan dua arah, dan degree of freedom Hifni Septina Carolina, et al., Pengembangan Instrumen... 
derajat kebebasan yang nilainya $=n$. Derajat kebebasan yaitu artinya 18 , berarti $\mathrm{r}_{\text {tabel }} 0,468$. Pada instrumen penilaian sikap, didapatkan hasil sebagai berikut:

Tabel 2. Hasil Uji produk Instrumen Penilaian Praktikum lapangan (outdoor) Aspek Sikap Ilmiah

\begin{tabular}{|l|l|l|}
\hline Item & Hasil & Keterangan \\
\hline $\begin{array}{l}\text { Mengidentifikasi objek (alat dan } \\
\text { bahan) }\end{array}$ & $\mathrm{r}_{\text {hitung }} 0,742>\mathrm{r}_{\text {tabel }} 0,468$ & valid \\
\hline $\begin{array}{l}\text { Mengamati ekosistem yang ada di } \\
\text { lingkungan sekolah }\end{array}$ & $\mathrm{r}_{\text {hitung }} 0,498<\mathrm{r}_{\text {tabel }} 0,468$ & valid \\
\hline $\begin{array}{l}\text { Menyajikan prediksi } \\
\text { Sederhana (hipotesis) }\end{array}$ & $\mathrm{r}_{\text {hitung }} 0,564>\mathrm{r}_{\text {tabel }} 0,468$ & valid \\
\hline $\begin{array}{l}\text { Menyusun rancangan awal untuk } \\
\text { menguji prediksi yang telah } \\
\text { dibuat dengan melakukan } \\
\text { percobaan sesuai dengan petunjuk } \\
\text { praktikum }\end{array}$ & $\mathrm{r}_{\text {hitung } 0,834>\mathrm{r}_{\text {tabel }} 0,468}$ & valid \\
\hline $\begin{array}{l}\text { Mengelompokkan komponen- } \\
\text { komponen ekosistem yang ada di } \\
\text { lingkungan sekolah }\end{array}$ & $\mathrm{r}_{\text {hitung }} 0,37<\mathrm{r}_{\text {tabel }} 0,468$ & drop \\
\hline $\begin{array}{l}\text { Mengelompokkan komponen- } \\
\text { komponen ekosistem yang ada di } \\
\text { lingkungan sekolah }\end{array}$ & $\mathrm{r}_{\text {hitung }} 0,63>\mathrm{r}_{\text {tabel }} 0,468$ & valid \\
\hline $\begin{array}{l}\text { Menginterpretasikan data } \\
\text { pengamatan yang } \\
\text { diperoleh }\end{array}$ & $\mathrm{r}_{\text {hitung } 0,542>\mathrm{r}_{\text {tabel }} 0,468}$ & valid \\
\hline $\begin{array}{l}\text { Membuat bagan tentang interaksi } \\
\text { antar komponen ekosistem yang } \\
\text { diamati }\end{array}$ & $\mathrm{r}_{\text {hitung } 0,247<\mathrm{r}_{\text {tabel }} 0,468}$ & drop \\
\hline $\begin{array}{l}\text { Membuat laporan } \\
\text { Percobaan disertai penggunaan } \\
\text { teori yang mendukung }\end{array}$ & $\mathrm{r}_{\text {hitung } 0,142<\mathrm{r}_{\text {tabel }} 0,468}$ & drop \\
\hline $\begin{array}{l}\text { Mengkomunikasikan di depan } \\
\text { kelas hasil pembuatan bagan } \\
\text { tentang interaksi antar komponen } \\
\text { ekosistem yang diamati. }\end{array}$ & $\mathrm{r}_{\text {hitung } 0,792<\mathrm{r}_{\text {tabel }} 0,468}$ & valid \\
\hline
\end{tabular}

Dari tabel tersebut dapat diketahui bahwa dari ke 10 item, terdapat 7 item yang valid yaitu layak untuk digunakan. Selanjutnya data dianalisis menggunakan uji reliabilitas dengan menggunakan uji Alpha cronbach. Dengan menggunakan $\alpha=0,05$, dengan n-2 maka 18-2 = 16, menghasilkan $\mathrm{r}_{\text {tabel }(\alpha=0,05)(16)}$ sebesar 0,468. Dari analisis didapatkan bahwa nilai $r_{h i t}=0,7758>r_{\text {tabel }} 0,468$ yang artinya item-item lembar observasi 
keterampilan proses sains pada kegiatan praktikum outdoor materi ekosistem dikatakan reliabel atau percaya sebagai alat pengumpul data. Hal tersebut menandakan $\mathrm{r}_{\mathrm{hit}}=0,7758$ termasuk ke dalam kriteria tinggi.

Pada instrumen penilaian keterampilan proses sains , didapatkan hasil sebagai berikut:

Tabel 3. Hasil Uji produk Instrumen Penilaian Praktikum lapangan (outdoor) Aspek Keterampilan Proses Sains

\begin{tabular}{|l|l|l|}
\hline Item Hasil & Keterangan \\
\hline $\begin{array}{l}\text { Disiplin dengan berdo'a } \\
\text { sebelum kegiatan pembelajaran } \\
\text { dimulai. }\end{array}$ & $\mathrm{r}_{\text {hitung } 0,642>\mathrm{r}_{\text {tabel }} 0,468}$ & valid \\
\hline $\begin{array}{l}\text { Disiplin dalam praktikum sesuai } \\
\text { dengan petunjuk kegiatan } \\
\text { praktikum. }\end{array}$ & $\mathrm{r}_{\text {hitung }} 0,5712>\mathrm{r}_{\text {tabel } 0,468}$ & valid \\
\hline $\begin{array}{l}\text { Disiplin dalam menggumpul } \\
\text { tugas hasil praktikum tepat } \\
\text { waktu. }\end{array}$ & $\mathrm{r}_{\text {hitung }} 0,5079<\mathrm{r}_{\text {tabel }} 0,468$ & valid \\
\hline $\begin{array}{l}\text { Melakukan pengamatan } \\
\text { ekosistem dengan teliti }\end{array}$ & $\mathrm{r}_{\text {hitung }} 0,2002<\mathrm{r}_{\text {tabel}} 0,468$ & drop \\
\hline $\begin{array}{l}\text { Menghargai pendapat teman } \\
\text { yang memberikan pendapat } \\
\text { ketika proses praktikum } \\
\text { berlangsung }\end{array}$ & $\mathrm{r}_{\text {hitung }} 0,4939>\mathrm{r}_{\text {tabel }} 0,468$ & valid \\
\hline $\begin{array}{l}\text { Bertanggungjawab dalam } \\
\text { menyusun laporan praktikum } \\
\text { secara mandiri. }\end{array}$ & $\mathrm{r}_{\text {hitung } 0,4908>\mathrm{r}_{\text {tabel }} 0,468}$ & valid \\
\hline $\begin{array}{l}\text { Bertanggungjawab dengan } \\
\text { membawa perlengkapan } \\
\text { kegiatan praktikum ekosistem }\end{array}$ & $\mathrm{r}_{\text {hitung } 0,628>\mathrm{r}_{\text {tabel }} 0,468}$ & valid \\
\hline $\begin{array}{l}\text { Bertanggungjawab untuk } \\
\text { menunjukkan sikap ilmiah pada } \\
\text { saat kegiatan praktikum. }\end{array}$ & $\mathrm{r}_{\text {hitung }} 0,539>\mathrm{r}_{\text {tabel }} 0,468$ & valid \\
\hline $\begin{array}{l}\text { Bekerjasama dalam pengamatan } \\
\text { ekosistem dilingkungan sekolah. }\end{array}$ & $\mathrm{r}_{\text {hitung } 0,1385<\mathrm{r}_{\text {tabel }} 0,468}$ & drop \\
\hline $\begin{array}{l}\text { Mengemukakan kelengkapan } \\
\text { hasil pengamatan }\end{array}$ & $\mathrm{r}_{\text {hitung } 0,5317>\mathrm{r}_{\text {tabel }} 0,468}$ & valid \\
\hline
\end{tabular}

Dari tabel tersebut dapat diketahui bahwa dari ke 10 item, terdapat 8 item yang valid yaitu layak untuk digunakan. Selanjutnya data dianalisis menggunakan uji reliabilitas dengan menggunakan uji Alpha cronbach. Dengan menggunakan $\alpha=0,05$, dengan n-2 maka 18-2 = 16, menghasilkan $\mathrm{r}_{\text {tabel }(\alpha=0,05)(16)}$ sebesar 0,468. Dari analisis didapatkan bahwa nilai $\mathrm{r}_{\text {hit }}=0,749>\mathrm{r}_{\text {tabel }} 0,468$ yang artinya item-item penilaian diri Hifni Septina Carolina, et al., Pengembangan Instrumen... 
sikap pada kegiatan praktikum outdoor materi ekosistem dikatakan reliabel atau percaya sebagai alat pengumpul data. Hal tersebut menandakan $r_{\text {hit }}=0,749$ termasuk ke dalam kriteria tinggi.

Pembelajaran berbasis praktikum dapat menjadi solusi untuk mengatasi rendahnya keterampilan proses sains dan sikap ilmiah siswa. Siswa akan lebih mudah mendapatkan pengalaman langsung dengan melakukan atau mempraktekkan sendiri. Senada dengan pendapat Djamarah (2005. Hal 77) bahwa kegiatan praktikum memberi kesempatan bagi peserta didik untuk mengalami sendiri, mencari kebenaran, atau mencoba mencari suatu hukum atau dalil, dan menarik kesimpulan atas proses yang dialaminya.

\section{KESIMPULAN DAN SARAN}

Berdasarkan hasil penelitian yang dilakukan dapat disimpulkan bahwa (1) Produk instrumen penilaian praktikum outdoor Biologi berhasil dikembangkan melalui metode design based research (DBR). (2) Hasil analisis data menunjukkan instrumen penilaian praktikum lapangan dari ahli materi sebesar 89,3 dengan kriteria sangat tinggi, penilaian dari ahli evaluasi sebesar 92,6 dengan kriteria sangat tinggi, dan penilaian ahi desain media sebesar 88,7 dengan kriteria sangat tinggi. Sehingga dapat disimpulkan bahwa instrumen penilaian praktikum lapangan (outdoor) biologi dinyatakan layak digunakan.

\section{DAFTAR PUSTAKA}

Arikunto, Suharsimi. 2010. Dasar-Dasar Evaluasi Pendidikan. Jakarta: Bumi Aksara. Charlesworth, R., \& Lind, K. K. 2010. Science For Young Children Sixth Edition. United States: Wadsworth Cengage Learning.

Chippetta dan E.L, Koballa, Th. R.Jr. 2010. Science Instruction in The Middle Andsecondary School Developin Fundament Knowledge and Skills. New York : Allyn \& Bacon.

Djamarah. 2005. Strategi Belajar Mengajar. Jakarta, Rineka Cipta.

Elseria. (2016). Efektifitas Pengelolaan Laboratorium IPA. Manajer Pendidikan.

Fuadi, Sumaryanto, Totok, Lestari, Wahyu. (2015). Pengembangan Instrumen Penilaian Psikomotor Pembelajaran IPA Materi Tumbuhan Hijau Berbasis Starter 
Experiment Approach Berwawasan Konservasi. Journal of Educational Research and Evaluation. JERE 4 (1) (2015)

Hazarianti, P., Masriani, \& Hadi, L. (2016). Pengembangan rubrik penilaian psikomotorik pada praktikum submateri koefisien distribusi mahasiswa pendidikan kimia. Jurnal Pendidikan Dan Pembelajaran.

Haerunnisa, H., Yani, A., \& Andani, C. (2018). Pengembangan Bahan Ajar Berbasis Worksheet Mata Kuliah Biologi Laut untuk MEningkatkan Sikap Ilmiah Mahasiswa.. Jurnal Biotek. https://doi.org/10.24252/jb.v6i2.5715

Husamah. (2013). Pembelajaran Luar Kelas, Outdoor Learning. Prestasi Pustaka: Jakarta.

Hidayah, Miftahul. 2017. Pengembangan Instrumen Penilaian Psikomotor pada Oudoor Practicum Biologi SMA. Didaktika. Vol 1 (2), Hal. 143-148

Lidinillah, D. A. M. (2012). Educational Design Research: a Theoretical Framework for Action. Universitas Pendidikan Indonesia-Kampus Tasikmalaya.

Toharudin, dkk. (2011). Membangun Literasi Sains Peserta Didik. Bandung, Humanlora, Hal.35.

Peraturan Menteri Pendidikan dan Kebudayaan Republik Indonesia Nomor 22 Tahun 2016 tentang Standar Proses Pendidikan Dasar dan Menengah.

Puspitasari, E. D., Susilo, M. J., \& Febrianti, N. (2019). Developing psychomotor evaluation instrument of biochemistry practicum for university students of biology education. Research and Evaluation in Education. https://doi.org/10.21831/reid.v5i1.22126

Suryaningsih, Y. (2017). Pembelajaran Berbasis Praktikum Sebagai Sarana Siswa untuk Berlatih Menerapkan Keterampilan Proses Sains dalam Materi Biologi. Bio Educatio. Volume 2, Nomor 2, Oktober 2017, hlm.49-57

Widiyatmono, Aji Farid (2014) "Efektivitas Pelaksanaan Praktikum Anatomi Hewan di Laboratorium Biologi ditinjau dari Nilai Praktikum”, Skripsi. Surakarta: Universitas Muhammadiyah Surakarta.

Yasbiati \& Asep S. (2014). Apa, Mengapa, dan Bagaimana Pendekatan Scientifik dalam Kurikulum 2013. Bandung: Pelangi Press Bandung. 